\title{
Comparative histopathological effects of aqueous, hexane extracts of Iraqi sweet almond (Prunus amygdalus) with atorvastatin for treating hyperlipidemia induced in mice
}

\author{
L.A. Kafi ${ }^{*}$ and N.TH.N. Al- Ezzi \\ *Department of Physiology and Pharmacology, College of Veterinary Medicine, University of Baghdad, Baghdad, Iraq
}

(Received August 9, 2016; Accepted September 18, 2016)

\begin{abstract}
This research was carried out to find out the treatment impact of aqueous and hexane extracts of sweet almond (Prunus amygdalus) on some histopathological indicators of heart, aorta and liver related to hyperlipidemia that induced in mice and compare them with Atorvastatin. Sweet almond was dried and grinded by an electrical grinder to form fine crude powder that extracted by two ways: by using $95 \%$ hexane and water by using the distilled water with Soxhlet apparatus. Forty mature mice were randomly divided into 8 groups ( 5 mice per group) and treated every day for 60 days, the first group was fed and drank normally and regarded as a negative control group, a second group was given polypropylene glycol offered as negative control group, third group was given tap water containing $0.5 \%$ of hydrogen peroxide and $1 \%$ of cholesterol in the feed for 60 days for induction of hyperlipidemia and offered as positive control group. Hyperlipidemia was induced in the other five groups as in the third group. The treatment of hyperlipidemia was done by using hexane extract at a dose of $500 \mathrm{mg} / \mathrm{kg}$ of body weight and aqueous extract of sweet almond with three different doses $(500,750$ and 1000) $\mathrm{mg} / \mathrm{kg}$ of body weight and compared with the other group that treated with atorvastatin $20 \mathrm{mg} / \mathrm{kg} \mathrm{B.W}$. as antihyperlipidemic drug. The outcomes discovered that histopathological changes of heart, aorta and liver exposed to hydrogen peroxide and cholesterol revealed congested blood vessels with inflammation relevant cells in their lumen with necrosis of hepatic cells and inflammation relevant cells collected in sinusoids and inner surfaces of the blood vessels and infiltration of macrophages and lymphocytes in the liver moreover to the infiltration of mononuclear cells in the heart while in the aorta showed the vacuolation in the sub intimae and vacuolation and increase the thickness of intimate layer. Furthermore, inflammation relevant cells particularly infiltration around aorta. While therapy with almond extracts and Atorvastatin lead to valuable changes in therapy of damaging happened in the heart, aorta and liver induced with hyperlipidemia. In addition a dose of $1000 \mathrm{mg} / \mathrm{kg}$ of aqueous extracts of sweet almond was the best in treatment of hyperlipidemia.
\end{abstract}

Keywords: Aqueous extract, antihyperlipidimic drugs, heart, liver, aorta Available online at http://www.vetmedmosul.org/ijvs

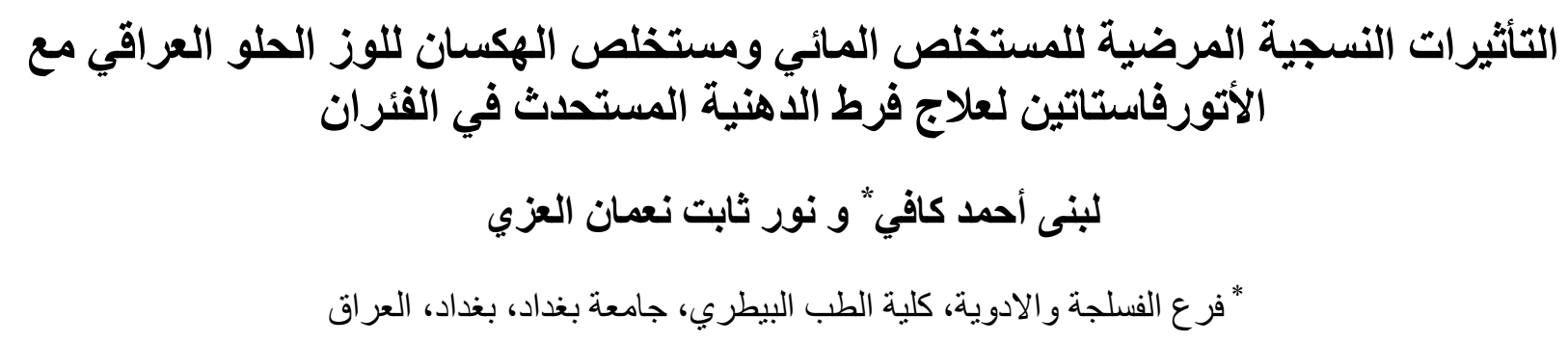

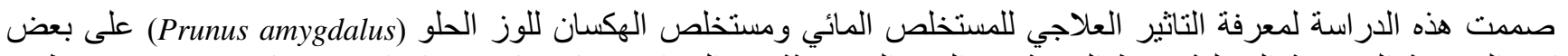

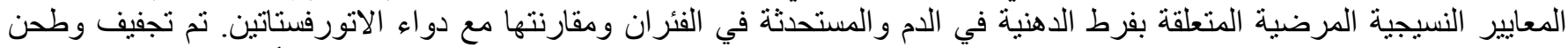

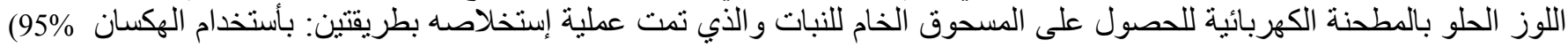




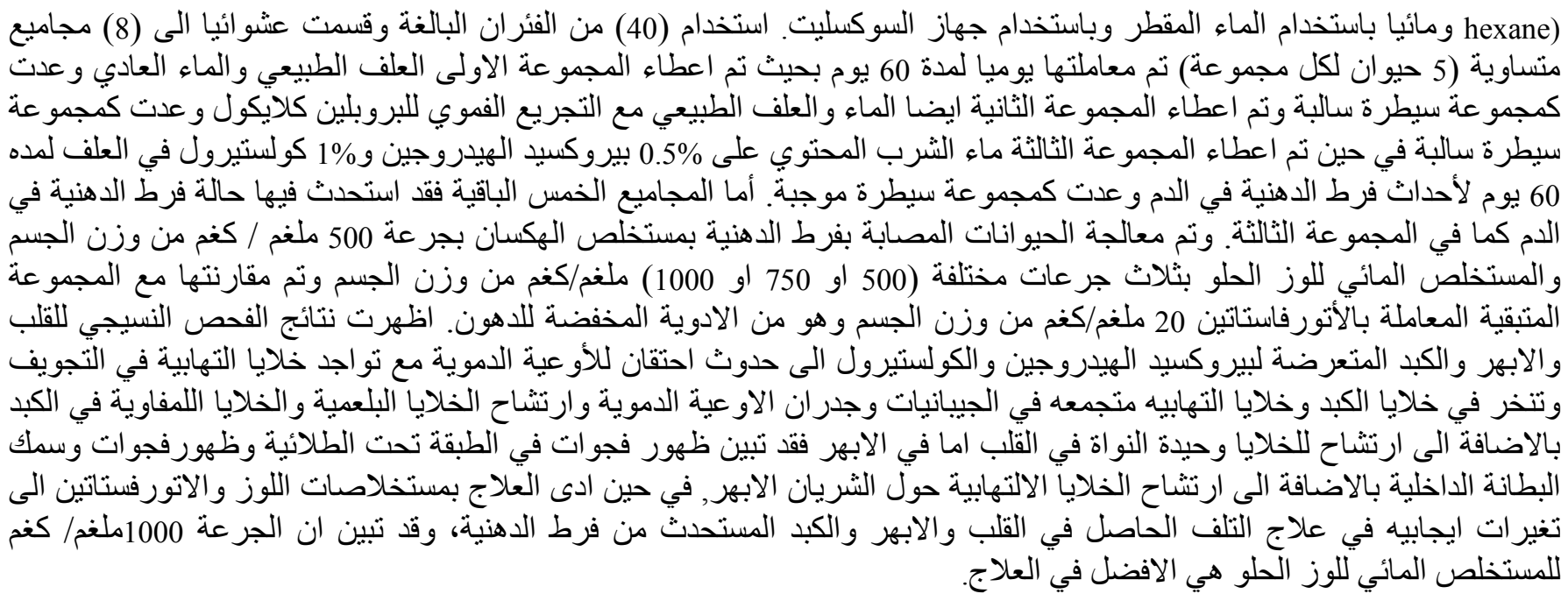

\section{Introduction}

Cardiovascular diseases are one of the leading causes of death all over the world (1). Dietary behavior has changed considerably in recent years. It has been demonstrated that the average consumption of starch and complex carbohydrates has decreased whereas the intake of fat, fatty acids and saturated fat, as well as simple carbohydrates has increased (2). Increased consumption of snacks and fast food, typically containing a high percentage of fat, has been observed in recent years. A sedentary lifestyle also contributes to a greater prevalence of elevated blood cholesterol levels. The indigenous system of medication provides a numerous information about vegetation available for therapy of hyperlipidemia. One such natural medicine in indigenous system stated to be useful in therapy of high fat build up in various organs. About $80 \%$ of the world population depend mainly on conventional medicinal practices which includes the use of vegetation for their main medical care (3).

Almond is an important food crop, varying in use from local consumption as an edible nut in its natural state to inclusion as a major ingredient in manufactured food products, the nutritional importance of almond fruit is related to its Kernel, which is concentrated as a source of energy, supplying significant amounts of fats, protein and fiber (4). Its beneficial effects on human health have been widely reported, especially in relation to the blood lipid profile and the risk of heart diseases (5). Hyperlipidemia and medicines are used to reduce blood cholesterol that has obtained generous exposure from last several years and hence, as a result, public is aware that high cholesterol stages levels are a threat aspect for cardiovascular disease. Atorvastatin are the first line treatment for decreasing lipid levels. Treatment of hyperlipidemia with statins has become a fundamental element of control of vascular diseases (6).

The aim of study is to do a comparative histopathological study among aqueous, hexane extracts of sweet almond (Prunus amygdalus) with Atorvastatin for treating hyperlipidemia induced in mice histologically.

\section{Materials and methods}

Sweet almond seeds were collected in the Erbil/ Kurdistan region-Iraq, the whole almond seeds sliced and dried in an oven in about temperature $25^{\circ} \mathrm{C}$ until the almonds become free of moisture (7). The extraction was carried out by Soxhlet apparatus using two methods hexane extract (8) and watery extract (9) that considered as a very effective in extracting the active ingredients of the almond. After that different doses given daily to mice orally by using gavages needle. The mice was divided into eight groups: group 1 negative control no induction of hyperlipidemia and given normal feed and distal water only, group 2 negative control no induction of hyperlipidemia and given normal feed, distal water and propylene glycol, group 3 positive control that induction of hyperlipidemia by addition of $1 \%$ cholesterol in diet (10) and $\mathrm{H}_{2} \mathrm{O}_{2} \quad 0.5 \%$ in drinking water (11) for two months and not treated, group 4 induction of hyperlipidemia and treated with hexane extract of sweet almond at a dose of $500 \mathrm{mg} / \mathrm{kg}$ B.W. for two months (12), groups 5, 6 and 7 induction of hyperlipidemia and treated with watery extract of sweet almond at a dose of $(500,750$ and 1000) $\mathrm{mg} / \mathrm{kg} \mathrm{B.W}$. for two months and group 8 induction of hyperlipidemia and treated with atorvastatin at a recommended dose $0.3 \mathrm{mg} / \mathrm{kg}$ B.W. for two months (13). At the end of the period of experiment, Autopsy of the liver, heart and aortic (abdominal and thoracic aorta) sectioning for 
histopathology then were done. At day 60, this phase of histopathology was the significant objective parameter that can confirm antiatherogenic effect of the tested agents as compared to untreated groups (the normal control groups and the induced group). The sacrified mice had been dissected through the chest wall; the heart along with the

\section{Results}

The results of the histological examination of heart, aorta and liver of mice feed normal diet and tap water during period of experiment showed normal structure in aorta (Fig. 1) and in heart (Fig. 2). On other hand the mice that feed normal diet and tap water in addition to oral administration of propylene glycol showed normal structure in organs as illustrated in aorta (Fig. 3). The microscopic examination of the liver in mice treated with $1 \%$ cholesterol and $0.5 \% \mathrm{H}_{2} \mathrm{O}_{2}$ in drinking water for eight weeks showed congested blood vessels with inflammatory cells in their lumen with necrosis of hepatic cells and inflammatory cells aggregation in sinusoids (Fig. 4) and wall of the blood vessels (Fig. 5). In addition to, the liver expressed necrosis area infiltrated with neutrophils and RBCs (Fig. 6), granulomatous lesions in their liver consisting of aggregation of macrophages and lymphocytes (Fig. 7). Microscopic examination of heart showed prominent mononuclear cells infiltration in epicardium (Fig. 8) and the aorta expressed vacuolation in the sub intima (Fig. 9). In other section, it was reported vacuolation and increase thickness of intima (Fig. 10), in addition inflammatory cells particularly infiltration around aorta (Fig. 11). The histological examination of the liver of mice treated with $500 \mathrm{mg} / \mathrm{kg} \mathrm{B.W}$. hexane extract of sweet almond for eight weeks showed granulomatous lesions in liver parenchyma with proliferation of Kupffer cells (Fig. 12), and the main lesions characterized by large necrotic area infiltrated with neutrophils and RBCs (Fig. 13). Microscopic examination in the heart and aorta there is no clear lesions. The histological examination of the liver of mice treated with $500 \mathrm{mg} / \mathrm{kg} \mathrm{B}$.W. watery extract of sweet almond for eight weeks showed granulomatous lesion in liver parenchyma with congested blood vessels and proliferation of Kupffer cells (Fig. 14), and in the aorta microscopic examination showed no clear lesions (Fig. 15). The histological examination of the liver of mice treated with $750 \mathrm{mg} / \mathrm{kg}$ B.W. watery extract of sweet almond for eight weeks showed multiple). granulomatous lesions in liver parenchyma and around blood vessels (Fig. 16), additionally in other section, the liver revealed proliferation of kupffer cells (Fig. 17). On the other hand the aorta showed no clear lesions (Fig. 18). The histological examination of the liver of mice treated with $1000 \mathrm{mg} / \mathrm{kg}$ B.W. watery extract of sweet almond for eight weeks showed mononuclear cells aggregation in wall of the blood connected full-length aorta such as most branching vessels was separated properly and placed in clean fixative solution. The liver sections were evaluated for histopathology to assess any architectural changes. These organs fixed in 10\% neutral formalin for 24-48 hours and prepare for histopathological examination $(14,15)$.

vessels with enlargement of Kupffer cells were the main lesions in the liver (Fig. 19). The heart examination showed no clear lesions (Fig. 20) and in the aorta there were no clear lesions (Fig. 21). The histological examination of the liver of mice treated with atorvastatin drug for eight weeks showed inflammatory cells particularly mononuclear cells and neutrophils in the lumen of congested and their wall as well liver parenchyma (Fig. 22). The main lesions in the heart consisting from inflammatory cells particularly mononuclear cells an neutrophils as well as edema between cardiac muscle fiber (Fig. 23), But in the aorta showed no clear lesions (Fig. 24).

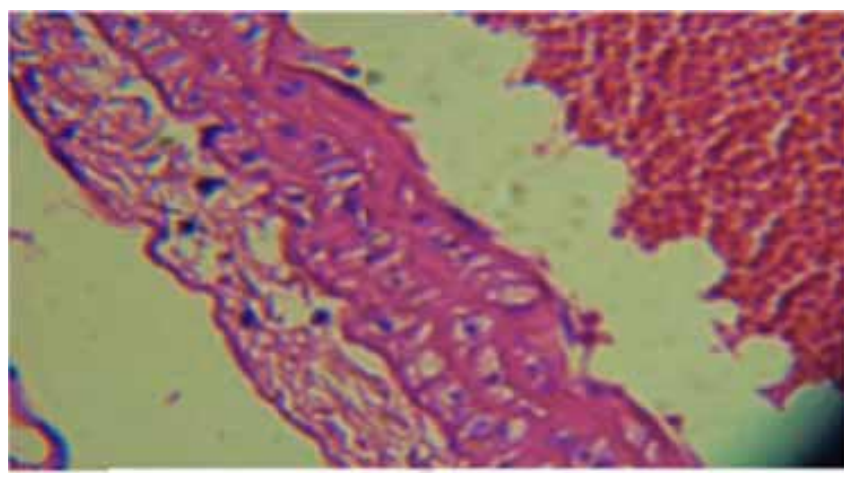

Figure 1: Histological section in the aorta of mice of negative control group showed normal structure (H\&E stain 40X).

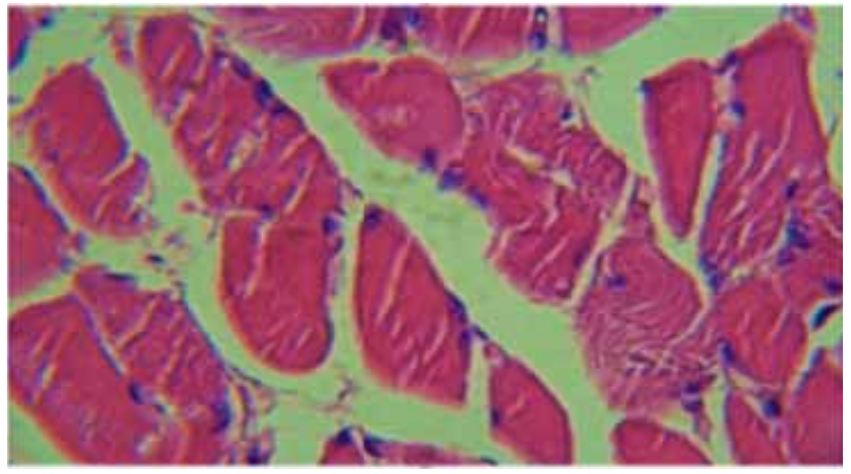

Figure 2: Histological section in the heart of mice of negative control group showed normal structure (H\&E stain 40X). 


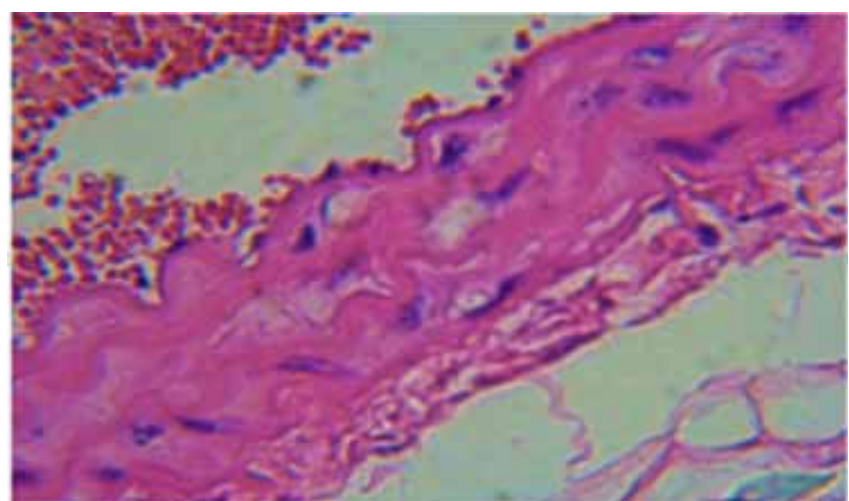

Figure 3: Histological section in aorta of mice at 60 days post-treatment with propylene glycol showed normal structure (H\&E stain 40X).

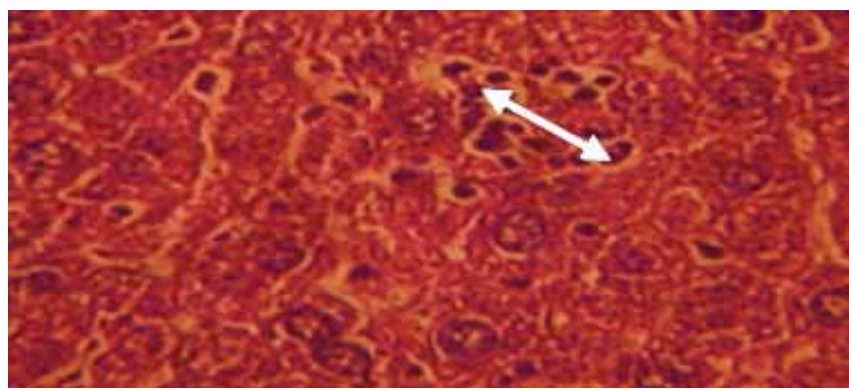

Figure 4: Histopathological section in the liver of mice at 60 days post-treatment with Cholesterol \& $\mathrm{H}_{2} \mathrm{O}_{2}$ showed mononuclear cells aggregation in the sinusoids $\leftrightarrow(\mathrm{H} \& \mathrm{E}$ stain $40 \mathrm{X})$.

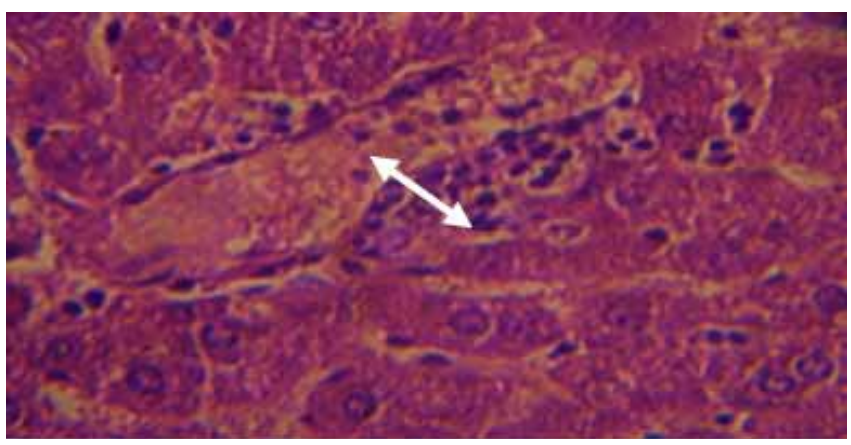

Figure 5: Histopathological section in the liver of mice at 60 days post-treatment with Cholesterol \& $\mathrm{H}_{2} \mathrm{O}_{2}$ showed mononuclear cells aggregation in the wall of congested blood vessels with inflammatory cells in their lumen $\leftrightarrow$ (H\&E stain 40X).

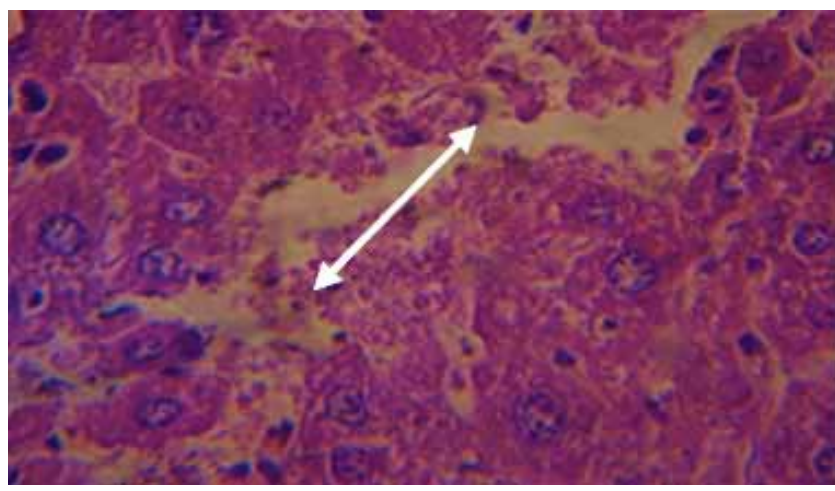

Figure 6: Histopathological section in the liver of mice at 60 days post-treatment with Cholesterol \& $\mathrm{H}_{2} \mathrm{O}_{2}$ showed necrosis area replacement with neutrophils and RBCs $\leftrightarrow$ (H\&E stain 40X).

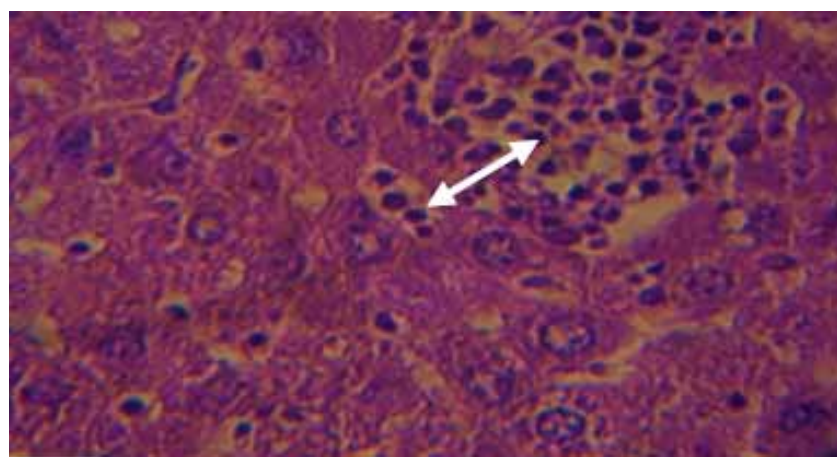

Figure 7: Histopathological section in the liver of mice at 60 days post-treatment with Cholesterol \& $\mathrm{H}_{2} \mathrm{O}_{2}$ showed granulomatous lesions consisting of aggregation of macrophages and lymphocytes in liver parenchyma $\leftrightarrow$ (H\&E stain 40X).

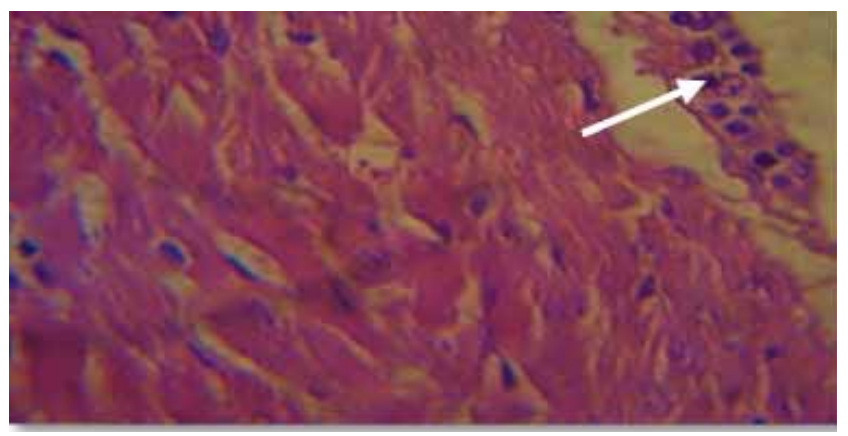

Figure 8: Histopathological section in the heart of mice at 60 days post-treatment with Cholesterol \& $\mathrm{H}_{2} \mathrm{O}_{2}$ shows mononuclear cells infiltration in pericardium $\rightarrow$ (H\&E stain $40 \mathrm{X})$. 


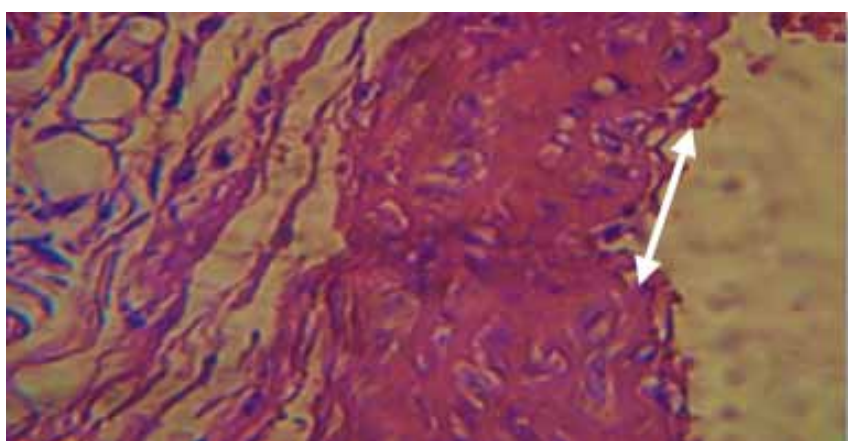

Figure 9: Histopathological section in the aorta of mice at 60 days post-treatment with Cholesterol \& $\mathrm{H}_{2} \mathrm{O}_{2}$ showed vacuolation in the sub intima $\leftrightarrow(H \& E$ stain $40 \mathrm{X})$.

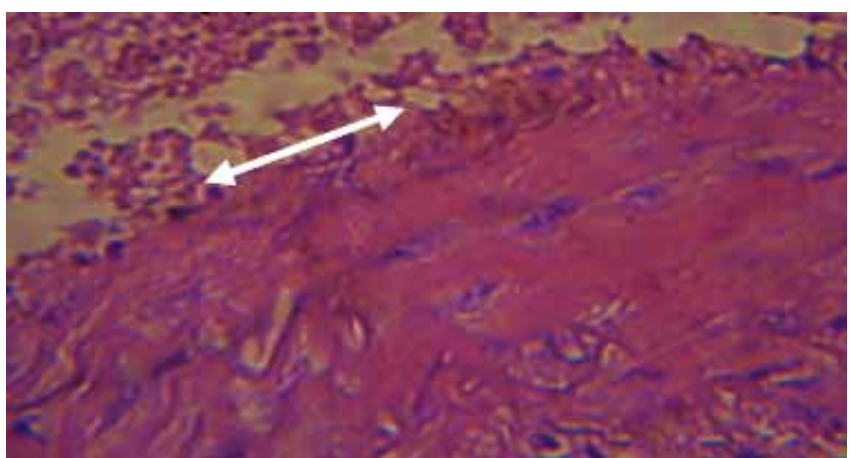

Figure 10: Histopathological section in the aorta of mice at 60 days post-treatment with Cholesterol \& $\mathrm{H}_{2} \mathrm{O}_{2}$ showed vacuolation and increase thickness of intima $\leftrightarrow$ (H\&E stain 40X).

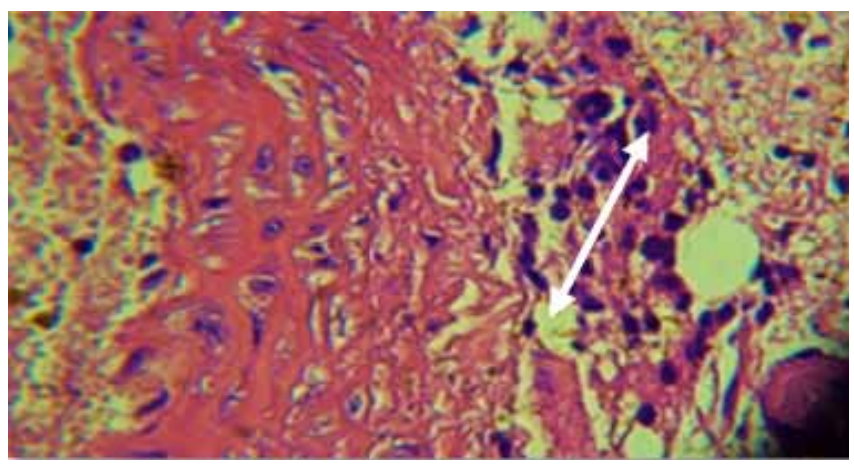

Figure 11: Histopathological section in the aorta of mice at 60 days post-treatment with Cholesterol \& $\mathrm{H}_{2} \mathrm{O}_{2}$ showed inflammatory cells infiltration particularly around aorta $\leftrightarrow$ (H\&E stain 40X).

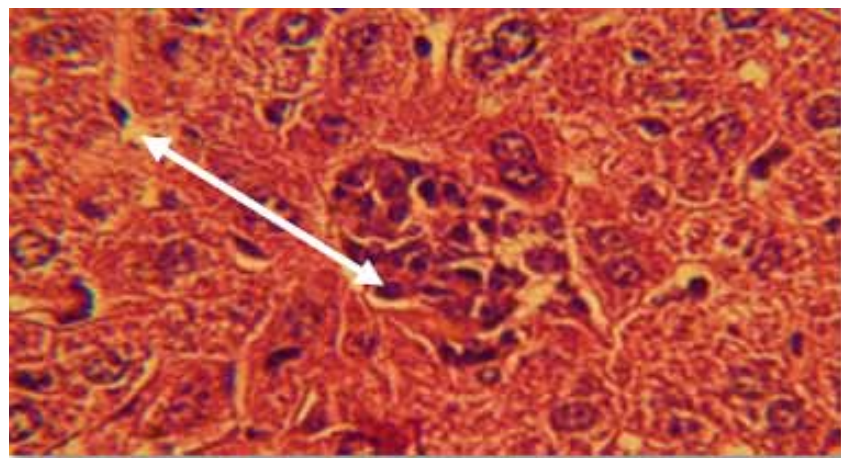

Figure 12: Histopathological section in the liver of mice exposure to $\mathrm{H}_{2} \mathrm{O}_{2}$ and treated with hexane extract of sweet almond at 60 days showed granulomatous lesions in liver parenchyma with proliferation of kupffer cells $\leftrightarrow(\mathrm{H} \& \mathrm{E}$ stain $40 \mathrm{X})$.

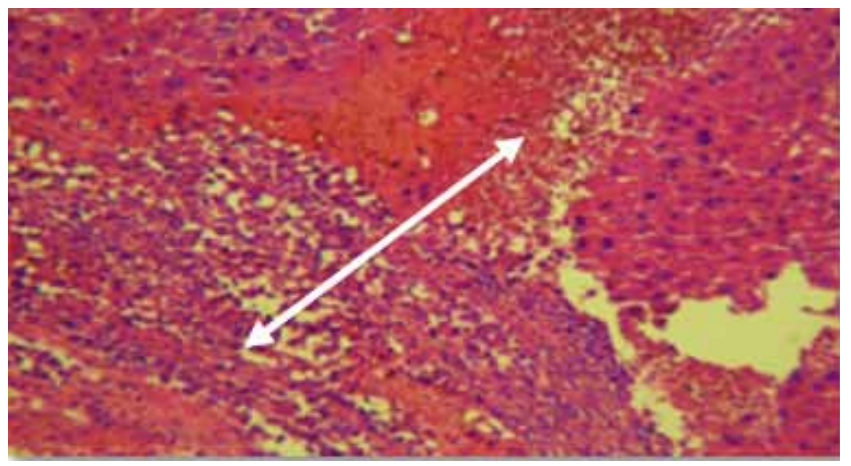

Figure 13: Histopathological section in the liver of mice exposure to $\mathrm{H}_{2} \mathrm{O}_{2}$ and treated with hexane extract of sweet almond at 60 days showed large necrotic area replacement with neutrophils and RBCs $\leftrightarrow$ (H\&E stain 40X).

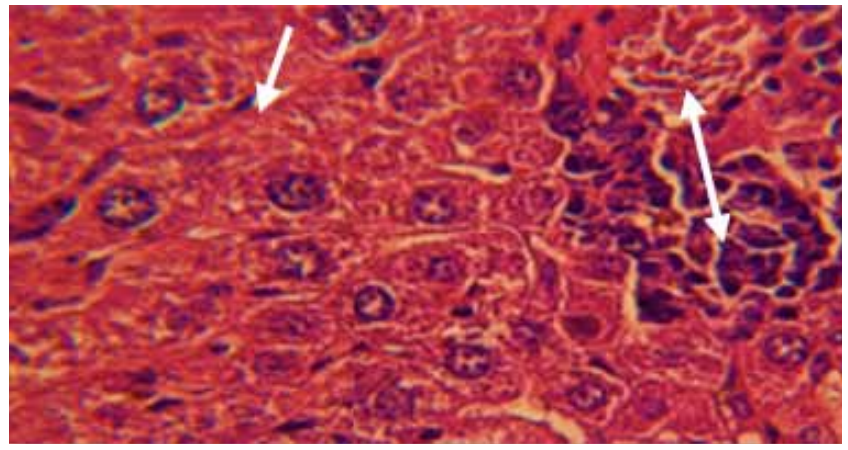

Figure 14: Histopathological section in the liver of mice exposure to the $\mathrm{H}_{2} \mathrm{O}_{2}$ and treatment with watery extracted of sweet almond $500 \mathrm{mg} / \mathrm{kg} \mathrm{B.W}$. at 60 days showed granulomatous lesion in liver parenchyma with congested blood $\leftrightarrow$ vessels and proliferation of kupffer cells $\rightarrow$ (H\&E stain 40X). 


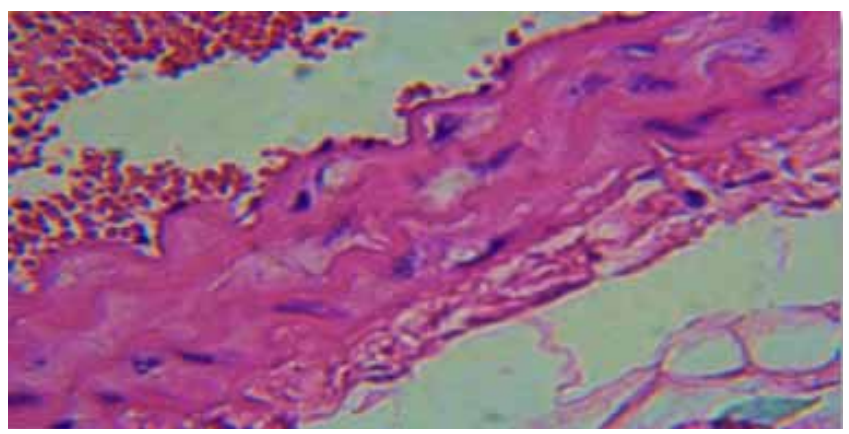

Figure 15: Histopathological section in the aorta of mice exposure to the $\mathrm{H}_{2} \mathrm{O}_{2}$ and treatment with watery extract of sweet almond $500 \mathrm{mg} / \mathrm{kg} \mathrm{B.W}$. at 60 days showed no clear lesions.

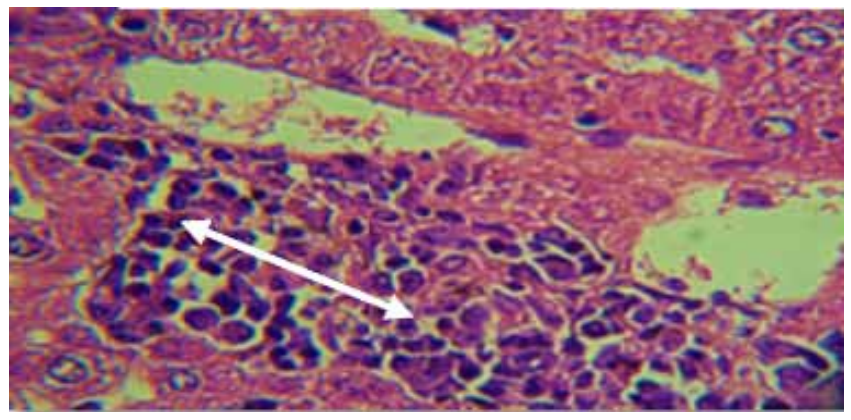

Figure 16: Histopathological section in the liver of mice at 60 days exposure to the $\mathrm{H}_{2} \mathrm{O}_{2}$ and treatment with watery extract sweet almond $750 \mathrm{mg} / \mathrm{kg}$ B.W. showed multiple granulomatous lesions in liver parenchyma and around blood vessels $\leftrightarrow$ (H\&E stain 40X).

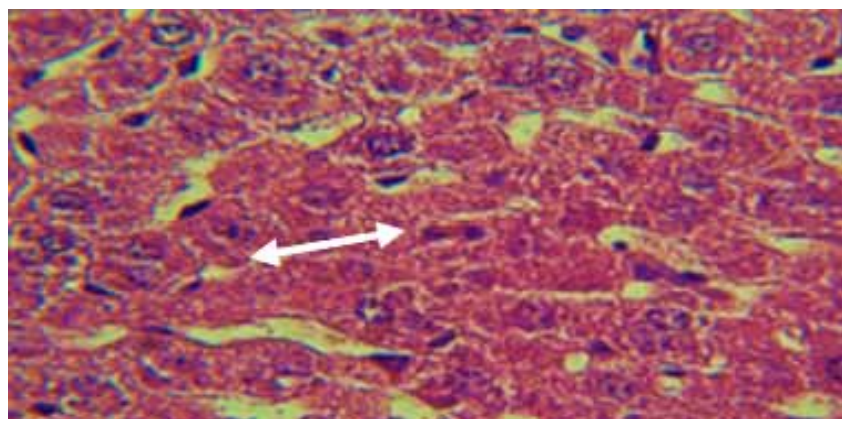

Figure 17: Histopathological section in the liver of mice exposure to $\mathrm{H}_{2} \mathrm{O}_{2}$ and treatment with watery extract sweet almond $750 \mathrm{mg} / \mathrm{kg} \mathrm{B.W}$. at 60 days showed proliferation of kupffer cells $\leftrightarrow$ (H\&E stain 40X).

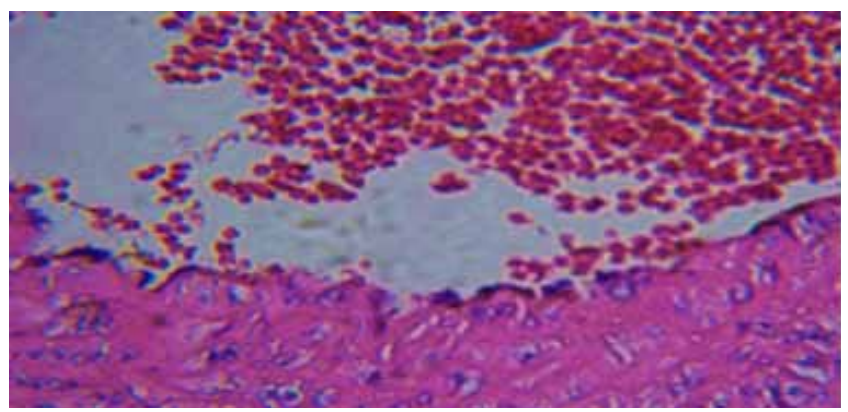

Figure 18: Histopathological section in the aorta of mice at 60 days post-treatment with watery extract sweet almond $750 \mathrm{mg} / \mathrm{kg} \mathrm{B}$.W. and exposure to the $\mathrm{H}_{2} \mathrm{O}_{2}$ shows no clear lesions (H\&E stain 40X).

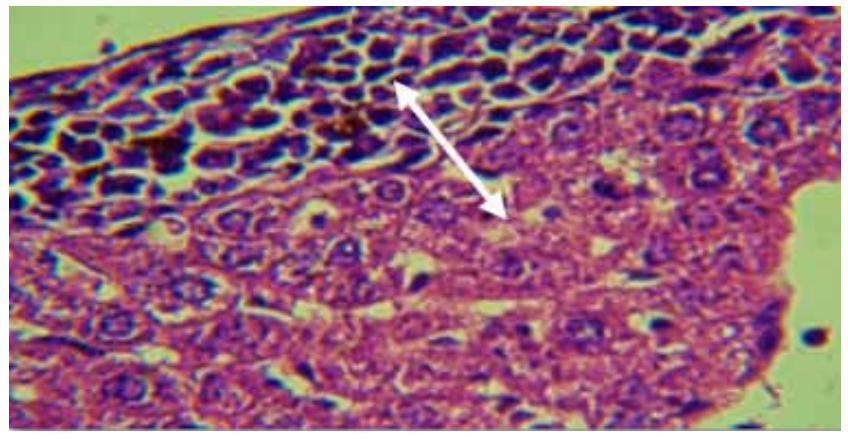

Figure 19: Histopathological section in the liver of mice exposure to $\mathrm{H}_{2} \mathrm{O}_{2}$ and treated with watery extract sweet almond $1000 \mathrm{mg} / \mathrm{kg} \mathrm{B.W}$. at 60 days showed mononuclear cells aggregation in wall of the blood vessels with enlargement of kupffer cells $\leftrightarrow$ (H\&E stain 40X).

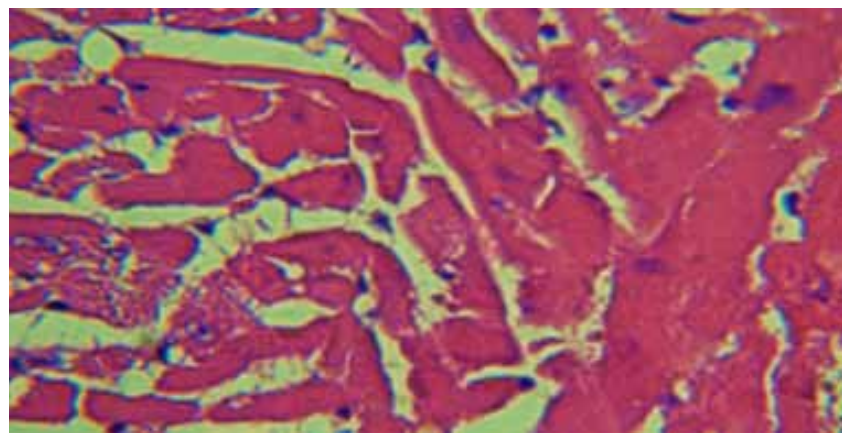

Figure 20: Histopathological section in the heart of mice exposure to $\mathrm{H}_{2} \mathrm{O}_{2}$ and treated with watery extract sweet almond $1000 \mathrm{mg} / \mathrm{kg} \mathrm{B.W}$. at 60 days showed no clear lesions (H\&E stain 40X). 


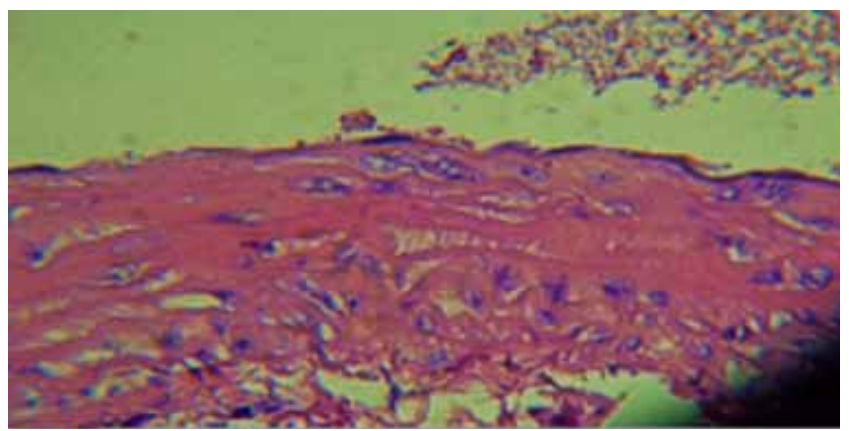

Figure 21: Histopathological section in the aorta of mice exposure to $\mathrm{H}_{2} \mathrm{O}_{2}$ and treated with watery extracted sweet almond $1000 \mathrm{mg} / \mathrm{kg} \mathrm{B.W}$. at 60 days showed no clear lesions (H\&E stain 40X).

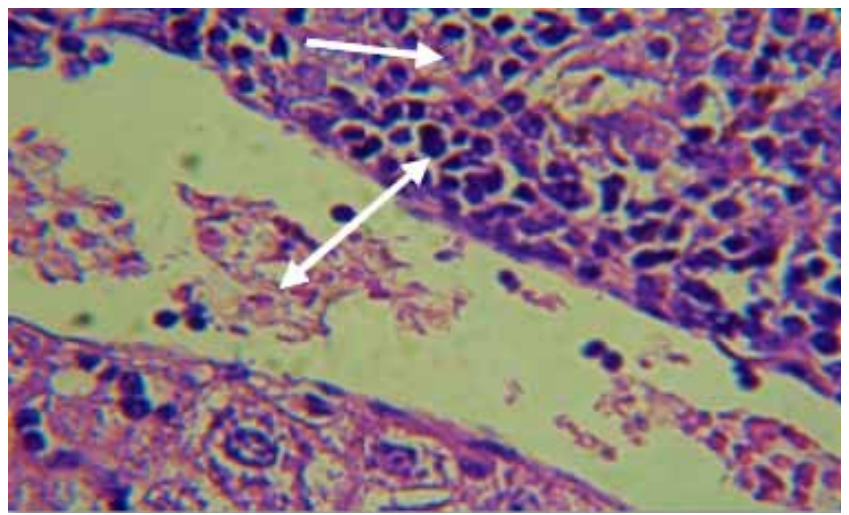

Figure 22: Histopathological section in the liver of mice exposure to $\mathrm{H}_{2} \mathrm{O}_{2}$ and treated with atorvastatin at 60 days showed inflammatory cells particularly mononuclear cells and neutrophils in the lumen of congested and their wall $\leftrightarrow$ as well liver parenchyma $\rightarrow$ (H\&E stain 40X).

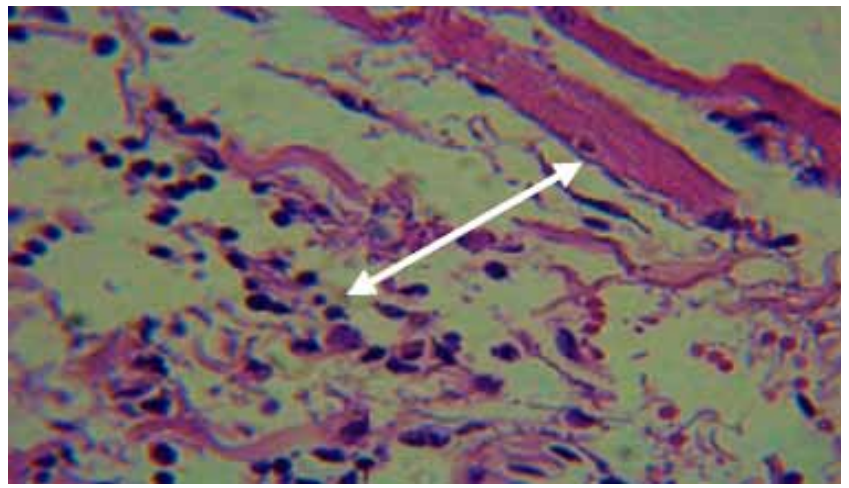

Figure 23: Histopathological section in the heart of mice exposure to $\mathrm{H}_{2} \mathrm{O}_{2}$ and treated with atorvastatin at 60 days showed inflammatory cells particularly mononuclear cells an neutrophils as well as edema between cardiac muscle fiber $\leftrightarrow$ (H\&E stain 40X).

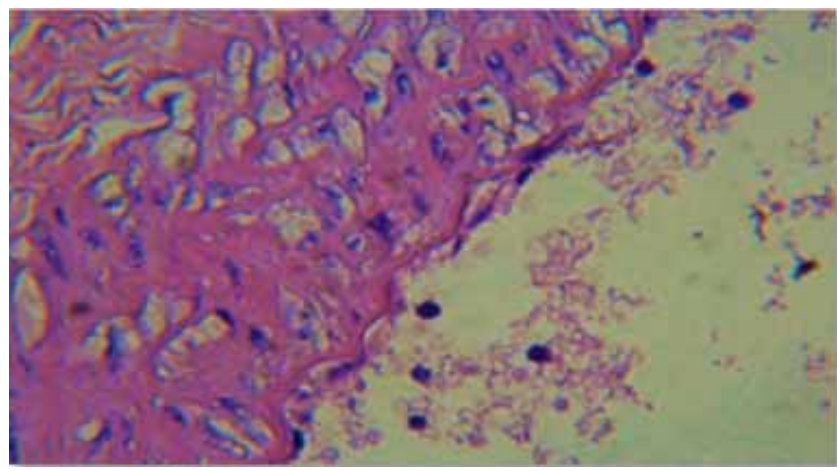

Figure 24: Histopathological section in the aorta of mice exposure to $\mathrm{H}_{2} \mathrm{O}_{2}$ and treated with atorvastatin showed no clear lesions (H\&E stain 40X).

\section{Discussion}

The results of histological examination after staining with hematoxylin-eosin of the liver, heart and aorta of mice received $1 \%$ cholesterol and $0.5 \% \mathrm{H}_{2} \mathrm{O}_{2}$ in drinking water for 60 days in this study revealed occurrence of hyperlipidemia and atheromatous aortic plaques. The present data in current study was in agreement with study of (16) who found that hypercholesterolemia activate the development of aortic atherosclerosis that often advances from fatty streak lesions to advanced, fibrous plaques. This finding is similar with the study of (17) who explained that in coronary artery disease, macrophages are important for intra cellular fat accumulation and foam cell development. In the aorta of the high-cholesterol diet categories, the flexible lamina layer was greatly damaged, and macrophages and foam cells were discovered.

Histological examination of the aorta and heart of mice received $0.5 \% \mathrm{H}_{2} \mathrm{O}_{2}$ in this study agreed with (18) that represented by intimal thickening in aorta and fatty change edema and hyalinization of myocardial muscle tissues associated with infiltration of inflammatory cells, mainly lymphocytes in heart. Results of histological changes in aorta and heart that may accept to damage that happens in the endothelium of aorta due to action of oxidative stress which is considered as an indication for injury and endothelial dysfunction. In addition, oxidative stress stimulates the generation of growth factors and active general ingredients showed by nitric oxide (NO) which activate endothelial vascular lesion that enhance mitogenic events and vascular smooth muscle cells (VSMc) proliferation (19).

The microscopic examination of the liver, heart and aorta of mice showed good response to sweet almond extracts in treatment of hyperlipidemia for eight weeks of experiment. In the current study presence of granuloma indicate to a crash tissue by $\mathrm{H}_{2} \mathrm{O}_{2}$, but when using sweet 
almond extracts lead to the activation of the immune system, particularly macrophages and lymphocytes which surrounded by tissue crashed and prevent its spread.

On other hand presence of monocular cell also refers to strengthen the immune system when sweet almond extracts treatment, the histological examination showed that sweet almond reduces existing lesions on the liver, heart and aorta due to antioxidant found in almond. Antioxidant agents treatments have been getting identification as strategies to reduce reactive oxygen species (ROS) in the vasculature thereby reducing their damaging effects (20).

Number of studies showed that sweet almond extracts contain of phytochemicals which play an important role in reducing risk of diseases, therefore, polyphenols could be valuable in preventing oxidative stress and thereby protect people from heart illnesses (21). The benefits of polyphenols have been linked mainly to their antioxidant potential and their capability to modulate cellular antioxidant defense mechanisms by inducing the synthesis of detoxification enzymes like SOD, CAT, glutathione Stransferase (GST), glutathione peroxidase (GPx) and NADPH (22). Flavonoids in almond ingredients appear to get a variety of biological activities such as anti-oxidant, anti-inflammatory and vasodilator actions (23).

Atorvastatin has anti-inflammatory actions through inhibition of certain matrix metalloproteinase (MMP) secretion from monocytes (24), macrophages and vascular smooth muscle cells as well as anti-proliferative and antimigratory results on vascular smooth muscle cells (25). The results of this research revealed that statins were effective in decreasing lipid peroxidation in native or oxidized LDL and also in the arterial walls. The antioxidizing impact of atorvastatin represents an essential step in protecting endothelial function (26). The increase in endotheliumdependent relaxation seen in the aortic rings of mice treated with atorvastatin should be relevant to the decrease in tissue cholesterol levels and oxidative stress in the arterial walls (27). Histological examination of the liver of mice treated with atorvastatin drug agreement with (28) that showed no fatty changes are visible in portal area of the liver showed hepatic artery and portal vein in addition lymph vessels and bile ducts, necrotic lesions were not seen in treated animals with drug.

\section{Conclusion}

The results of present study showed that the using of sweet almond extract in different methods of extraction and in doses especially $100 \mathrm{mg} / \mathrm{kg} \mathrm{BW}$ of watery extract is benefit to treat hyperlipidemia best than atorvastatin.

\section{References}

1. Goff DC, Bertoni AG, Kramer H,Bonds D, Blumenthal RS, Tsai MY, Psaty BM. Dyslipidemia prevalence, treatment and control in the multi-ethnic study of atherosclerosis (MESA): gender, ethnicity, and coronary artery calcium. Circulation. 2006;113(5):647-656.

2. WHO. Healthy nutrition. Preventing nutrition-related diseases in Europe. WHO Regional publications. European Series.1988;24:127.

3. Owolabi OJ, Omogbai EKI, Obasuyi O. Antifungal and antibacterial activities of the ethanolic and aqueous extract of Kigella africana (Bignoniaceae) stem bark. Afr J Biotechnol. 2007;6:1677-1680.

4. Akpambang VOE, AmooI A, Izuagie AA. Comparative compositional analysis on two varieties of melon (Colocynthis citrullus and Cucumber psisedulis) and a variety of almond (Prunus amygdalus). Res J Agri Biolo Sci. 2008;4(6):639-642.

5. Chen CY, Lapsley K, Blumberg J. A nutrition and health perspective on almonds. J Sci Food Agric. 2006;86:2245-2250.

6. Alvin Jose M, Anandkumar S, Narmadha MP, Sandeep M. A comparative effect of atorvastatin with other statins in patients of Hyperlipidemia. Indian J Pharmacol. 2012;44(2):261-263.

7. AL-Younis, Argushy. Antibacterial evaluation of some medicinal plants from Kurdistan region. J Duhok Univ. 2009;12(1):256-261.

8. Durmaz H, saguna E, Tarakci Z, Ozgokce F. Antibacterial activity of allium vineale chaerophllum macropodum and prangosferulacea. Afr. J Bioteh. 2006;5(19):1795-1798.

9. Wang L, Weller CL. Recent advances in extraction of nutraceuticals from plants. Trends in Food Sci. Technol. 2006;17(6):300-312.

10. Adaramoye OA, Akintayo O, Achem J, Fafunso MA. Lipid-lowering effects of methanolic extract of Vernonia amygdalina leaves in rats fed on high cholesterol diet. Vasc Health Risk Manag. 2008;4(1):235241.

11. Tarmooz AA. The effective dose of sweet almond suspension (Prunus amygdalus) compared with some antihyperlipidemic drugs in experimentally induced mice with hyperlipidemia. Thesis, Veterinary Medicine Pharmacology and Toxicology, Baghdad, Iraq, 2014.

12. Etim OE, Bassey EI, Ita SO, Udonkang IC, Etim IE, Jackson IL. Modulatory effect of sweet almond extract on serum lipids, lipid peroxidation and histology of pancreas in aloxan induced diabetic rats. Inter Res Pharmacut Pharmaco. 2011;1(7):155-161.

13. AL-Rawi MM, Maisaa M. Efficacy of oat bran (Avena sativa L.) in comparison with atorvastatin in treatment of hypercholesterolemia in albino rat liver. Egyp J Hospital Med. 2007;29:511- 521.

14. Luna LG. Manual of Histological staining method of the Armed forces Institute of pathology. $3^{\text {rd }}$ ed. Mc. Graw-Hill Book Company New York; 1968.

15. Williamson E, Okpako M, Evans FJ. In pharmacological methods in phytotherapy research, (Wiley and Sons publications, USA), $\operatorname{vol}(1) ; 1996$.

16. Temel RE, Rudel LL. Diet effects on atherosclerosis in mice. Current Drug Target. 2007;8:1150-60.

17. Takahashi K, Takeya M, Sakishima N. Multifunctional roles of macrophages in the development and progression of atherosclerosis in humans and experimental animals. Medical Electron Microscopy: official J Clin Elect Micro Soci Japan. 2002;35:179-203.

18. Al-Kennany ER, Al-Khafaf AI. Role of oxidative stress induced by hydrogen peroxide on initiation and development of atherosclerosis in mature female rat. Iraqi J Vet Sci. 2006;20 (1):139-151.

19. Malden LT, Chait A, Raimes EW, Ross R. The influence of oxidatively modified growth factor by human monocyte-derived macrophages. J Biol Chem. 1991;25:13901-13907.

20. Hamilton CA, Miller WH, Al-Benna S, Brosnan MJ, Drummond RD, McBride MW, Dominiczak AF. Strategies to reduce oxidative stress in cardiovascular disease. Clin Sci (Lond.). 2004;106:219-234.

21. Habauzit V, Morand C. Evidence for a protective effect of polyphenols-containing foods on cardiovascular health: An update for clinicians. Ther Adv Chronic Dis. 2012;3:87-106. 
22. Rodrigo R, Miranda A, Vergara L. Modulation of endogenous antioxidant system by wine polyphenols in human disease. Clin Chim Acta. 2011;412:410-424.

23. Nijveldt RJ, van Nood E, van Hoorn DEC, Boelens PG, van Norren $\mathrm{K}$, van Leeuwen PA. Flavonoids: a review of probable mechanisms of action and potential applications. Amer J Clin Nutr. 2001;74:418-425.

24. Grip O, Janciauskiene S, Lindgren S. Atorvastatin activates PPARgamma and attenuates the inflammatory response in human monocytes. Inflamm Res. 2002;51(2):58-62.

25. 25.Luan Z, Chase AJ, Newby AC. Statins inhibit secretion of metalloproteinases-1, $-2,-3$, and -9 from vascular smooth muscle cells and macrophages. Arterioscler. Thromb. Vase. Biol. 2003;23(5):769775 .

26. 26.Tesfamariam B, Frohlich BH, Gregg RE. Differential effects of pravastatin, simvastatin, and atorvastatin on $\mathrm{Ca}++$ release and vascular reactivity. J Cardiovasc Pharmacol. 1999;34:95-101.

27. 27.Joukhadar C, Klein N, Schrolnberger C, Vukovich T, Wolzt M, Dorner GT. Similar effects of atorvastatin, simvastatin, simvastatin and pravastatin on thrombogenic and inflammatory parameters in patients with hypercholesterolemia. Thromb. Haemost. 2001;85:4751.

28. 28.Gartner PL, Hialt JL. Colour Atlas of Histology, 3rd ed. Lippincott Williams and Wilkins, Philadelphia. 2000;pp.160-328. 